\title{
Rural and agroindustrial tourism as a factor of socio-cultural and economic development of the territory
}

\author{
A. A. Oshkordina ${ }^{*}$, and E. G. Radygina \\ Ural State University of Economics, 620144 Yekaterinburg, Russia
}

\begin{abstract}
The paper discusses current issues and problems of organizing and implementing event and tourist activities as an effective tool for popularizing and attracting attention to rural areas, which, in the context of the COVID 19 preventive campaign around the world, is a relevant factor for many categories of the population. The authors have identified the positive and negative factors of tourist activities organization, affecting the socio-cultural and economic level of rural development. The main directions of organization, implementation and development of rural and agroindustrial tourism on the territory of a separate subject of the Russian Federation have been determined. Most important, in the current difficult conditions of the tourist industry development, in many territories of Russia domestic tourism is becoming a priority, focusing, among other things, on the creation of new products of rural and agroindustrial tourism.
\end{abstract}

\section{Introduction}

In current socio-economic conditions, the multiplier effect of tourism can make a significant contribution to the economy development of rural areas as a factor of additional financial resources; it promotes the formation of the territory social infrastructure, as well as facilitates the popularization and increase of the cultural, cognitive and patriotic consciousness of the population. Today, event tourism in rural areas does not have a massive character; the exception is the ubiquitous dacha tourism, which showcases a high level of popularity in Russia. It should be remembered that the events of the past year have seriously reoriented the activities of travel companies to create new tourist products, primarily domestic ones, most of which belong to rural tourism. Therefore, in our opinion, the popularization and attractiveness of rural tourism in modern conditions are relevant and require regulatory and financial support from the government. In addition, today there is no clear understanding of the terminological apparatus and the concept of "rural tourism", which greatly complicates the process of collecting, processing and evaluating information and statistical data in the organization and implementation of event, excursion and tourist activities in rural areas.

Rural tourism is not only a certain tribute to the widespread fashion, but also a kind of necessity for the urban population living in an unfavorable ecological and psycho-

\footnotetext{
* Corresponding author: al2111la@yandex.ru
} 
emotional environment of the modern and dynamically changing rhythm of life. A holiday in the countryside aims to combine enjoying the nature and learning historical, cultural and ethnographic aspects of the heritage, such as customs, crafts, national cuisine, clothing, etc. of the population living in the territory. In addition, rural tourism can also develop a research focus in the form of collecting folklore, learning local languages and dialects, collecting plant and mineral raw materials and substances, etc. According to I. V. Smirnova, the population, tired of the hustle and bustle of a big city, seeks to relax physically, mentally, to enjoy the beauty of nature, to touch the cultural heritage of historically significant places, which are not as popular as those in large tourist centers [1].

This study aims to identify the main directions of rural tourism development as a factor of increasing socio-economic efficiency of rural areas of the Sverdlovsk region.

Thus, the territory of our country, including the Sverdlovsk region, has a powerful potential of natural, landscape, climatic, cultural, historical, ethnic and economic resources. This potential ensures implementation of various types of tourist activities in rural areas. At the same time, it should be noted that the implementation of ideas and activities in rural areas can be possible only in environmentally friendly territories that are not touched by industrial production, which pollutes the environment of rural areas.

\section{Materials and methods}

The study was conducted on the statistical, accounting, reporting, and information data on the activities of travel industry organizations and enterprises located in the Sverdlovsk region. The study also included research data from the related works by domestic and foreign scientists in the field of rural and agroindustrial tourism. While processing and systematizing the information and analytical data we applied such methods of study as grouping, detailing, synthesis, historical and logical research method, as well as methods of economic analysis.

\section{Results and discussion}

A group of Russian scientists T.A. Volkova, V.V. Minenkova, D.V. Maksimov. rightly claim the existence of prototypes of rural and agroindustrial tourism in the pre-Soviet and Soviet period, in contrast to many young scientists, who define rural tourism as a relatively young type of tourist activity, though quite a promising one [2]. So, agrotourism dates back to the times when travelers using horse-drawn carts had to stop for the night at an inn in the countryside. Later, in the 17th century, in Russia, summer vacations at dachas (country houses) gained wide popularity with the nobles, and that can be considered as a closer predecessor of modern agrotourism [3]. Since the beginning of the Soviet Union, almost the entire population, from schoolchildren to those ending their work life, including students of secondary vocational and higher educational institutions, were engaged in the system of agroindustrial activities through involvement in agricultural work. During the existence of the Soviet Union, labor and recreation camps were organized for schoolchildren and students with a round-the-clock stay in rural areas. Employees in all branches and subsectors of the national economy took an active part in agricultural work of the nearby collective and state farms. Thus, the involvement of almost the entire working-age population of the Soviet Union aged 12 to 60 did not merely enable to obtain economic effects for agricultural enterprises; it realized an educational and cognitive function for the young people, while fostering diligence, mutual assistance, curiosity, solidarity, love for their native land and Motherland, etc. 
Currently, in many countries of the world, such as Switzerland, France, Italy, Spain, Ireland, Scandinavian countries, rural tourism is undergoing rapid development, both from the perspective of domestic and inbound tourism, while attracting a significant number of domestic and foreign visitors from all over the world. According to expert assumptions and calculations, the annual profit of rural tourism in these countries is more than a hundred million dollars.

Russia ranks 5th in the world in terms of agricultural land [4]. According to Rosstat (Russian Statistics), the rural population on January 1, 2019 was 37.5 million people, or about $25 \%$ of the entire population of the Russian Federation [5]. According to the AllRussian Agricultural Census that took place in 2016, the number of peasant (farm) households decreased compared to 2006 and was 136.6 against 253.1 thousand, and the number of individual entrepreneurs in the countryside increased from 32 to 38 thousand. At the same time, the average land area per farm for the specified period increased from 102.6 to 268.9 hectares, and for individual entrepreneurs - from 106.2 to 149.0 hectares [6]. Yet, the official statistics indicate the inconsistency and ambiguity of economic processes and patterns in the development of agriculture in Russia (Table 1).

Table 1. Socio-economic criteria for rural areas development in Russia [7]

\begin{tabular}{|l|c|c|c|c|c|}
\hline \multicolumn{1}{|c|}{ Criteria } & 2014 & 2015 & 2016 & 2017 & 2018 \\
\hline $\begin{array}{l}\text { Average annual number of } \\
\text { employees, people }\end{array}$ & 4921 & 4900 & 4890 & 4481 & 4346 \\
\hline Number of workplaces & 21759 & 21868 & 21902 & 20923 & 21191 \\
\hline Average wage, roubles & 17194 & 19238 & 21268 & 23529 & 25820 \\
\hline Number of profitable farms, $\%$ & 73,6 & 77,0 & 77,7 & 75,6 & 73,8 \\
\hline Number of unprofitable farms, $\%$ & 26,4 & 23,0 & 22,3 & 24,4 & 26,2 \\
\hline
\end{tabular}

The analysis of Table 1 indicates a decrease in the average annual number of agricultural workers in 2018 by almost $12 \%$ compared to the base year of 2014, which can also indicate positive developments in this economy sector associated with the introduction and use of innovative technical tools and technologies, as well as with the labor automation in agriculture, which reduces the amount of manual labor. Unfortunately, along with the implementation of automation tools in large agroindustrial farms, a decrease in the average annual number of employees in this economy sector can be associated with an outflow of labor resources from sparsely populated areas, which in turn leads to a high demand for qualified personnel in rural areas. At the same time, the reduction in the average annual number of workers by $12 \%$ led to the reduction in the number of workplaces in agriculture by only $3 \%$, which once again confirms the possible fact of the widespread replacement of heavy manual labor with highly efficient automated labor. Yet, the level of wages in agriculture during the analyzed time period has a tendency of annual growth by an average of $9-11 \%$, though this is two times lower than the average wage in the country. A more detailed cross-section of agricultural workers' wages in different regions of the Russian Federation proves that the wage level varies. The number of profitable farms varies approximately within the same limits and averages $75 \%$; about $25 \%$ of farms suffer losses. In our opinion, it is the attraction of tourist flows for the purpose of visiting the countryside that can create conditions for increasing the profitability of farms.

According to S. K. Volkov, over the past decade rural tourism has begun to actively develop in Russia, namely in the Altai Territory, Kaliningrad, Leningrad and Pskov Regions, Krasnodar Territory, and the Republic of Bashkortostan. Tourism experts do not get tired of predicting the unprecedented scale of rural tourism development, for which Russia has enormous resources [8]. Thus, it is necessary to stress an increase in the volume of tourist flows within rural and agroindustrial tourism throughout the whole territory of the Russian Federation. At the same time, it is necessary to note the consumers' dynamically 
changing preferences and demands; it requires attracting investments in order to form recreational and socio-cultural infrastructure in rural areas. Thus, the implementation of event and tourist activities in rural areas solves a number of socio-economic problems: raising the socio-economic level of rural development by increasing the number of tourist flows; saving and increasing jobs by raising the interest of the local population in the revival of national culture and their ancestors' identity; developing recreational and social infrastructure in rural areas; preserving natural resources; creating small enterprises for souvenir manufacturing and crafts development in sparsely populated areas.

Yet, despite the dynamically developing rural tourism on the territory of the Russian Federation in recent years, the industry is now experiencing serious problems that require immediate solutions. Thus, according to I. L. Polyakova and M. P. Grigorieva, the current state of rural tourism in Russia and its development trends make it possible to identify a number of factors that hinder its further development:

- insufficient support for rural tourism as a separate branch of the economy;

- undeveloped legislative and regulatory framework;

- lack of a comprehensive system for stimulating rural tourism;

- poorly developed tourist infrastructure, including the transport system;

- low living standard of the rural population of Russia's regions;

- insufficiently effective mechanism for managing the rural tourism sector;

- unfavorable climate conditions;

- terrorism, unfavorable crime situation;

- underdeveloped rural infrastructure;

- weak promotion of the agricultural product in the domestic and international markets;

- lack of a recognizable brand;

- low level of investment in rural tourism;

- lack of support programs for rural areas [9].

N. A. Mironova describes the development of agrotourism in Russia as follows: "Unfortunately, at the moment, the development of agrotourism in Russia is a declared slogan, without any progressive movements in this direction. With assistance of the state, an association for agrotourism promotion has even been launched, which declares a large number of objectives on its own website, but judging by the activity on the portal and the nearly total absence of news updates, the real activity of the association is either at an extremely low level, or completely absent" [10]. O. K. Slinkova states the following priority measures that can give an impetus to agro-tourism development in the Russian Federation: developing a legislative framework to regulate functioning of this sector of tourism; providing support for agrotourist farms in the form of preferential loans for the tourist infrastructure development; developing and implementing regional programs to support agrotourism[11].

Thus, rural and agrotourism development is directly proportional to the state assistance in the field of legal, organizational and managerial support for tourist businesses with the possibility of attracting industrial capital. And thus, the actualization of the activities, which aim at organizing and implementing new tourist products and events in rural areas, is caused by their powerful impact on the level of socio-economic and demographic development of rural areas.

The territory of the Sverdlovsk region was formed on January 17, 1934 and is located on the border of Europe and Asia at the intersection of transcontinental flows of raw materials, goods, financial, labor and information resources. The Sverdlovsk region today is a large economically developed territory of Russia with a high level of business, cultural and social activity, one of the most promising subjects of the Russian Federation. According to the official statistics, the permanent population of the region at the beginning of 2021 is 4 million 290 thousand people, of which $85 \%$ is urban, and only $15 \%$ is rural. 
There are 47 cities, 26 working settlements and urban-type settlements, 1804 rural settlements on the territory of the region [12].

Despite the harsh climatic conditions, agriculture is developing rapidly in the Sverdlovsk region. So, at the beginning of 2021, 390 agricultural organizations, more than 970 peasant and farm households and entrepreneurs are engaged in agriculture, about 440 thousand people have subsidiary farms. According to the latest data, more than 818.0 thousand hectares in the Sverdlovsk region are allocated for sown areas for agricultural crops; more than 24 thousand people are officially employed at agricultural enterprises. Thus, according to the main socio-economic development criteria, the Sverdlovsk Region is among the top ten regions of the Russian Federation. In addition, the socio-cultural infrastructure formed on the territory of the region enables many rural areas to implement event, sports and tourist activities.

Table 2. Implementation of tourist events in agricultural territories of the Sverdlovsk region in 2021

\begin{tabular}{|l|c|c|}
\hline \multicolumn{1}{|c|}{ Indicators } & Number of events & Specific gravity, \% \\
\hline Total event activities & 350 & 100 \\
\hline Yekaterinburg & 102 & 29 \\
\hline Municipalities & 191 & 55 \\
\hline Rural areas & 57 & 16 \\
\hline
\end{tabular}

Given the data of the Tourism Development Center of the Sverdlovsk region on the implementation of tourist events, the following conclusions can be drawn: annually, more than 350 events of various types take place on the territory of the Sverdlovsk region; about a third of all events are held in the administrative center of the region - the city of Yekaterinburg; municipalities of the region show a high level of activity in the implementation of event tourism, the share of which is more than half of the total number of events declared; only $16 \%$ falls on the implementation of activities in rural areas. In addition, it is necessary to reflect the fact that 28 of the activities presented in Table 2 are carried out in seven rural settlements, i.e. more than half of the tourist activities in rural areas are organized by nearly the same settlements that have long been involved in tourist flow organization and are increasingly participating in these processes every year. If we talk about the degree of active participation in the events of all rural areas of the region, we have to state a sad fact: only about 30 rural settlements of the region out of 1804 take at least some part in the organization and implementation of tourist activity, which primarily indicates a low level of interest of both the rural population and the authorities of rural administrations and agricultural enterprises. At the same time, in recent years, the government of the Sverdlovsk Region has provided event organizers in sparsely populated towns and settlements with a unique opportunity to apply for financial, organizational and legal support free of charge.

As an example, we would like to mention a unique young project in the village of Marmorskoye - "Day of Marble Music" within the "Marble Mile" («Mramornaya milya») project, which was successfully launched in 2019 with the support of the "Idea" («Ideya») Social Activity Fund, the head of the village of Marmorskoye Vera Nufer and the board of the "Ural Marble" («Ural'skiy mramor») enterprise. For the second time, in a spent marble quarry, at the bottom of an ancient sea, musicians performed music pieces of various composers and eras. According to the results of the "Russian Event Awards" competition, this project was recognized as the best regional tourist project, and the Sverdlovsk region took the 1st place in the rating of the All-Russian Award in the field of event tourism [13].

Another unique project, known for over 40 years and attracting the attention of tourists not only from the Sverdlovsk region, but also from other regions - "Nizhnyaya Sinyachikha and the Museum-Reserve of Wooden Architecture". It is noteworthy that this project 
implementation was initiated by a single person, Ivan Danilovich Samoilov. He went to the realization of his idea for many years, starting in 1967. Today, the Nizhnyaya Sinyachikha Museum-Reserve of Wooden Architecture is the only museum of this kind on the territory of the Sverdlovsk Region. In the Middle Urals, it can be compared to the museum in Khokhlovka, Perm Region [14]. Every month, Nizhnyaya Sinyachikha is visited by 100 to 500 tourists, attracting additional funds, forming the social and cultural infrastructure of the territory, and creating new jobs for the population. Today, the museum-reserve serves as a basis for children's and youth's "circles" and folklore groups, which pursue the goal of preserving the cultural heritage and traditional national crafts, while fostering patriotism and love for the native land and fatherland among the younger generation. It is in Nizhnyaya Sinyachikha that from 6 to 10 events take place annually, attracting visitors from various regions of our country and from abroad. Thus, Nizhnyaya Sinyachikha is proof of possible organization and implementation of projects when there is personal interest and activity of the local population.

Nizhnie Tavolgi, an old Ural village with a population of about 350 people, has been famous for its pottery since ancient times. Together with Verkhniye Tavolgi, the village has recently organized a center of folk crafts. A modern tourist infrastructure has been created, providing a comfortable stay on the territory of these settlements. There have been developed tourist routes, which vary in duration and thematic component: 1) a hike along the path of power with a visit to the springs of living and dead water and Ermak rock; 2) a trip to the Old Believers' skete "Bogodan"; 3) a visit to the cult center of the Neolithic period - Shaitan lake. The presence of a tourist social infrastructure facilitates organizing festivals of a regional and international scale, such as the tea eco-festival "When Tavolga Blossoms" («Kogda tsvetet Tavolga»), the Festival of arts and crafts "Secrets of the Gemstone Ring" («Tayny samotsvetnogo kol'tsa»), etc. Thus, the territory is actively developing and creating additional jobs due to implementation of tourist projects and products.

\section{Conclusions}

In the current socio-economic conditions of rural areas development, organization and implementation of rural tourism can play an important part. At the same time, the share of agrotourism in the Russian tourist market does not exceed $2 \%$ [15]. The availability of a huge variety of natural, climate and geographic, cultural and ethnic, and historical riches of Russia's rural areas, including the Sverdlovsk region, makes it possible to organize and implement tourist products with a high degree of competitiveness, which in turn will ensure solving various problems of socio-economic and cultural nature in rural areas. At the same time, rural tourism today has not received a mass character on the territory of Russia, but has the so-called point distribution and directly depends on the activity and initiatives of the local population and rural administrations. Yet, the implementation of rural tourism ideas and projects requires support from the state authorities.

Thus, to meet the challenge and develop agrotourism in Russia, in our opinion, it is necessary to:

- develop legal documents regulating tourist activity at all stages of its implementation;

- develop regional target programs that aim to provide financial support for current projects and ideas of rural tourism organization;

- attract financial resources from private organizations and investors on a preferential or gratuitous basis;

- raise the population awareness of the possibilities to participate in various event activities of rural tourism by means of mass media; 
- update the development of short-term weekend tourist products with the use of event tourism elements (hiking, making products of folk art with your own hands, engaging in agricultural work, collecting medicinal herbs, making agricultural products, etc.);

- popularize thematic corporate events, weddings, banquets, children's parties, etc. on the territory of agricultural enterprises.

The complex of developed measures, in our opinion, is to increase and facilitate agrotourism popularization in rural areas. In current conditions, agrotourism should be perceived as an effective economic tool for rural areas development from various perspectives.

\section{References}

1. I. V. Smirnova, Bulletin of the Mari State University, 1(13), 87-90 (2014)

2. T. A. Volkova, V. V. Minenkova, D. V. Maksimov, A. A. Ponamorenko, Scientific journal of KubSAU, 132(08) (2017)

3. V. V. Minenkova, D. V. Maksimov, T. A. Volkova, Yu. I. Karpova, Global scientific potential, 8(41), 7-13 (2014)

4. Site of the Federal State Statistics Service, http://www.gks.ru

5. Agriculture in Russia, 2019: Statistical collection, Rosstat, 91 (2019)

6. All-Russian agricultural census of 2016, Preliminary results: Statistical Bulletin, 7 (2016)

7. Agriculture in Russia, 2019, Statistical collection, Rosstat, 91 (2019)

8. S. K. Volkov, Economics, entrepreneurship and law, 6(17) (2012)

9. I. L. Polyakova, M. P. Grigorieva, Service in Russia and abroad, 11(5), 31-43 (2017)

10. N. A. Mironova, Moscow Economic Journal, 5 (2020)

11. O. K. Slinkova, Scientific result, Business and service technologies, 3(3), https://cyberleninka.ru/

12. Official website of the government of the Sverdlovsk region, http://midural.ru/

13. Information portal "ProPolevskoy", https://propolevskoy.ru/

14. Pavel Raspopov, Lower Sinyachikha and the Museum-Reserve of Wooden Architecture, https://uraloved.ru/

15. What hinders the development of agritourism in Russia? http://www.agropages.ru/ 